\title{
NORMAS PARA OS COLABORADORES
}

A Revista Brasileira de Estudos Politicos somente aceita trabalhos inéditos. Os textos deverão versar sobre a Linha Editorial da revista, cujo detalhamento consta no link "Foco e Escopo" do nosso site. Os trabalhos podem ser encaminhados a qualquer momento para os e-mails: rbep.ufmg@gmail.com e rbep@direito.ufmg.br, indicando título, autoria e até quatro qualificações acadêmicas do autor. $\mathrm{O}$ autor deve necessariamente possuir o título de Doutor, sendo aceitos textos em coautoria de doutorandos e seus respectivos orientadores. O autor deverá informar seu nome completo, endereço para correspondência, e-mail, filiação institucional e identificar a modalidade do trabalho. Artigos escritos em coautoria devem seguir todas as normas definidas acima para cada um de seus autores. Os trabalhos serão recebidos pela Secretaria da RBEP, que os remeterá, sem identificação, à análise de pareceristas anônimos para avaliação qualitativa de forma e conteúdo (double-blind peer review). O parecer pode determinar o aceite para publicação, a sugestão de modificações ou a recusa do artigo. O autor terá acesso a todos os pareceres sobre seu artigo, sem identificação do parecerista. Os artigos aprovados e que venham a sofrer modificações oriundas das sugestões dos pareceristas deverão ser novamente enviados para a RBEP. Os trabalhos 
devem ser escritos em um dos seguintes idiomas: português, inglês, alemão, espanhol, francês ou italiano e devem obedecer aos seguintes requisitos:

\section{Primeira página:}

a) Título na língua de redação do texto e em inglês (se o texto estiver redigido em língua inglesa, deverá, obrigatoriamente, trazer título em um dos outros idiomas citados).

b) Resumo na língua de redação do texto e em inglês (abstract) com, no máximo, 200 palavras, contendo o campo de estudo, objetivo, método, resultado e conclusão (se o texto estiver redigido em língua inglesa, deverá, obrigatoriamente, trazer resumo em um dos outros idiomas citados).

c) De 3 a 5 palavras-chave na língua de redação do texto e em inglês (se as palavras-chave estiverem redigidas em língua inglesa, deverão, obrigatoriamente, ser apresentadas também em um dos outros idiomas citados).

d) Início do texto.

\section{Citações:}

a) As citações devem ser feitas em nota de rodapé, indicando os dados da fonte conforme o seguinte modelo: GALEANO, 1981, p. 159.

b) As referências completas devem ser apresentadas em ordem alfabética no final do texto, de acordo com as normas da NBR-6023/ABNT e seguindo o seguinte modelo: 


\section{Livro:}

NIETZSCHE, Friedrich Wilhelm. Assim falou Zaratustra: um livro para todos e para ninguém. Trad. Mário da Silva. 9. ed. Rio de Janeiro: Civilização Brasileira, 1998.

Capítulo de livro:

CUNHA, José Ricardo. Fundamentos axiológicos da hermeneutica jurídica. In: BOUCAULT, Carlos E. de Abreu e RODRIGUEZ, José Rodrigo (Org.). Hermeneutica plural. São Paulo: Martins Fontes. pp. 309-351, 2002.

Artigo:

SOMEK, Alexander. Stateless law: Kelsen's conception and its limits. In: Oxford Journal of Legal Studies, v. 26, n. 4, pp. 753-774, 2006.

c) Diagramas, quadros e tabelas devem possuir título e ter a fonte indicada em nota de rodapé.

\section{Estrutura formal:}

a) Tamanho do papel: A4.

b) Editor de texto: word.doc ou word.rtf.

c) Fonte: Times New Roman, 12.

d) Margens: esquerda, superior, direita e inferior: $2,5 \mathrm{~cm}$.

e) Parágrafo, espaçamento anterior e posterior: 0 ponto.

f) Entre linhas: duplo.

g) Alinhamento: justificado. 


\section{Extensão:}

Artigos até 30 laudas.

\section{Disposiçõos finais:}

Os artigos enviados são de responsabilidade exclusiva do(s) autor(es). Cada autor receberá 1 (um) exemplar da revista em que seu texto for publicado.

Todos os artigos devem ser encaminhados à revista acompanhados de endereço profissional completo (Cidade, Estado, CEP e País), indicação da Instituição de Ensino, Unidade e Departamento a que pertencem os autores, bem como seus e-mails de contato, informações que serão divulgadas na revista caso o texto seja aprovado. Ao enviar colaborações para a revista, os autores se obrigam a informar o editor sobre eventuais conflitos de interesse que possam vir a surgir no processo de avaliação e na publicação do respectivo texto. Tais conflitos serão submetidos à avaliação e à decisão irrecorrível do Conselho Científico. Os direitos autorais dos textos publicados na Revista Brasileira de Estudos Políticos permanecem sob a propriedade de seus respectivos titulares, devendo, contudo, toda remissão ao texto publicado na revista fazer referência à mesma. 


\section{DIRECTIVES FOR CONTRIBUTIONS}

The Brazilian Journal of Political Studies - RBEP (Revista Brasileira de Estudos Políticos) - only accepts previously unpublished essays. Submissions must have thematic pertinence with the general topics of interest of the journal, which are described in the link "Focus and Scope" of our site. Contributions may be submitted at any time to the following e-mail addresses: rbep.ufmg@gmail.com and rbep@direito.ufmg.br, indicating the title, the author's name and up to four qualifications of the author. The author must necessarily possess the title of $\mathrm{PhD}$, being accepted texts in co-authorship of $\mathrm{PhD}$ candidates and their respective advisers. The author must inform his/her complete name, mailing address, e-mail addresses, institutional affiliation, as well as the modality of the contribution (whether it is an article, shorter essay or review). Contributions written by more than one author must follow these directives for each of the co-authors. Contributions are received by the secretary of the RBEP, which will send them without any sort of identification to anonymous reviewers for qualitative assessment of the contents of the contribution and of formal aspects. The reviewers may accept the contribution, suggest modifications or refuse it altogether. The author will have access to all the reviews of his/her contribution, without 
identification of the reviewer. The articles accepted for publication which need further modifications derived from suggestions of the reviewers must be re-submitted to RBEP. The contributions may be written in one of the following languages: Portuguese, English, German, Spanish, French or Italian and must obey the following rules:

\section{Opening page:}

The opening page must contain:

a) The title in the language of the text and in English (if the text is written in English it must include the title in one of the other languages of the journal).

b) An abstract in the language of the text and in English with up to 200 words, including the subject area, the purposes, the method, the result and the conclusion (if the text is written in English it must contain an abstract in one of the other languages of the journal).

c) From 3 to 5 keywords in the language of the contribution and in English (if the keywords are already in English they must be translated into one of the other languages of the journal).

d) The beginning of the contribution.

\section{Bibliographical references:}

a) References must be given on footnotes, referring to the source according to the following standard: GALEANO, 1981, p. 159.

b) The complete references must be presented in alphabetical order at the end of the text, according 
to the norms of regulation NBR-6023/ABNT of the Brazilian Association of Technical Norms, according to the following model:

\section{Books:}

NIETZSCHE, Friedrich Wilhelm. Assim falou Zaratustra: um livro para todos e para ninguém. Trad. Mário da Silva. 9. ed. Rio de Janeiro: Civilização Brasileira, 1998.

WEBER, Max. Economy and society. Trans. Guenther Roth and Claus Wittich. 2. ed. Berkeley: University of California, 1978.

\section{Book Chapter:}

CUNHA, José Ricardo. Fundamentos axiológicos da hermeneutica jurídica. In: BOUCAULT, Carlos E. de Abreu e RODRIGUEZ, José Rodrigo (Org.). Hermeneutica plural. São Paulo: Martins Fontes. pp. 309-351, 2002.

PERRY, Setephen R. Hart's methodological positivism. In: COLEMAN, Jules (org.). Hart's postscript: essays on the postscript to "the concept of law". Oxford: Oxford University, 2001.

\section{Article:}

SOMEK, Alexander. Stateless law: Kelsen's conception and its limits. In: Oxford Journal of Legal Studies, v. 26, n. 4, pp. 753-774, 2006.

c) Diagrams, boards and tables must have a title and have their sources indicated on footnotes.

\section{Structure of the paper:}

a) Size of paper: A4.

b) Format of file: .doc or .rtf. 
c) Source: Times New Roman, 12.

d) Margins: left, superior, right and inferior: 2,5 cm.

e) Paragraphs, space before and after: 0 pt.

f) Space between lines: double.

\section{Extension:}

Articles up to 30 pages.

\section{Final regulations:}

The authors of the contributions published at RBEP are fully and exclusively responsible for their papers. Each author shall receive one copy of the volume of the journal in which his/her text is published.

Submissions of manuscripts to the Brazilian Journal of Political Studies shall include a cover sheet containing the full professional address (including city, state or province, postal code and country), the institutional affiliation of the authors, as well as their preferred e-mail addresses. This information will be displayed at the journal in case the manuscript is accepted for publication. While submitting contributions to the journal, the authors must inform the editor about eventual conflicts of interests that may occur during the reviewing process and the publication stage. These conflicts will be resolved by a single and non-reviewable decision of the Scientific Board. The copyrights of the essays published at the Brazilian Journal of Political Studies are property of their authors. Nevertheless, any remission to the text published at the journal must mention its publication therein, including full bibliographical references. 